\title{
Civilising the Citizens: Political Slogans and the Right to the City
}

\author{
Maurizio Marinelli, University of Technology Sydney
}

Happiness for the people is like flowers.

The people and the Party shall create the proper environment for the flowers to grow.

(Wang Yang 2011)

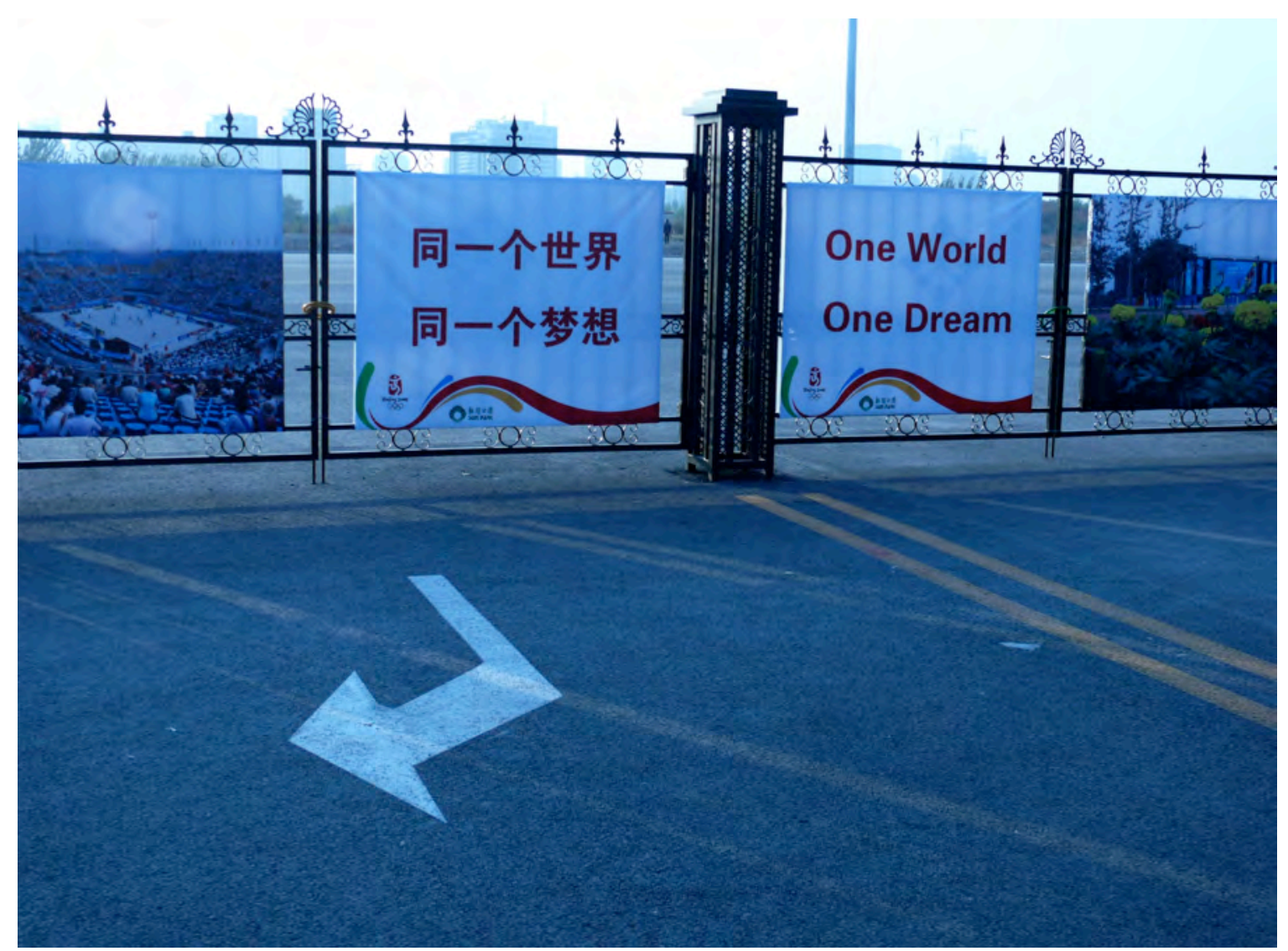

Figure 1: Billboard ‘One world—One dream.' Beijing, 2007 (C) Maurizio Marinelli 


\section{Preface}

One evening in August 2007, Chinese artist Zhang Dali 张大力 was riding his bicycle back home. When he reached the fourth ring road east he saw a mega-billboard with the slogan Tongyi ge shijie tongyi ge mengxian 同一个世界 同一个梦想. This Chinese language image-word is usually translated as 'One world—One dream.' However, if one respects the etymology, it should be translated as: 'Same world-Same dream.' This slogan conveys the crucial idea that China today is not only part of the world, but is also assertively positioning itself as a leading global player in the twenty-first century.

Zhang Dali pondered upon the deeper content of this slogan and found it 'absolutely shocking' (juedui zhenhan 绝对震撼). The slogan helped Zhang realise that the imminent opening of the Olympic Games' mega-event (8-22 August 2008) offered the best possible opportunity for the Chinese State to exhibit to the whole world both its economic achievements and the political strength of the Party. At the same time, besides acknowledging the Chinese State's strategic intention to use the Beijing Olympics as a public relations opportunity, Zhang Dali's 'shock' also derived from his recognition of the use of traditional revolutionary-style mobilisation tactics. This twofold shocking experience led Zhang Dali to conclude that, if one compared the incredible transformation of the economic productive structure with what had happened in the world of ideas (sixiang 思想), ${ }^{2}$ the mode of thinking of the government (zhengfu de siwei 政府的思维) had not significantly changed. According to the artist, although the Chinese government in 2007 was organising the Olympic Games, the techniques to coin the present slogans and the realm of ideas from the revolutionary era onwards had remained mostly unchanged. The sameness concealed by the slogan was exactly this: the same ideology had pervasively persisted (jiu shi tongyi sixiang 就是同一思想).

This article will begin with an analysis of the political context in which the Beijing Olympics were conceptualised. This will shed light on their rationale, and provide a full understanding of the Government-created logocentric model to hail the mega-event and proclaim China's success story. The analysis of the official slogans in the first part of the article will provide the necessary background to investigate the origin of Zhang

\footnotetext{
${ }^{1}$ The slogan echoes the typical expression: xiang tongyi mubiao qianjin 向同一目标前进, which literally means 'to advance towards the same goal.'

${ }^{2}$ Personal interview with the artist, July 2011. In Chinese, sixiang 思想 refers also to ideology, and therefore to the realm of political thought and political awareness.
} 
Dali's artwork entitled 'The Slogan Series.' The artist is particularly interested in exploring 'the real society (shehui xianshi 社会现实).' His denunciation of the violence of the Olympics hegemonic language, led him to appropriate the official slogans to create thought-provoking text-images, with the aim of preventing collective amnesia. The analysis of Zhang's work will reveal the aesthetics and socio-political implications of his artworks, which originate from his dual intention to problematise what happened to the 'real society' in the city where he lives and, at the same time, to bridge the gap between art and 'real' space, asserting the right to a new language to inhabit the city.

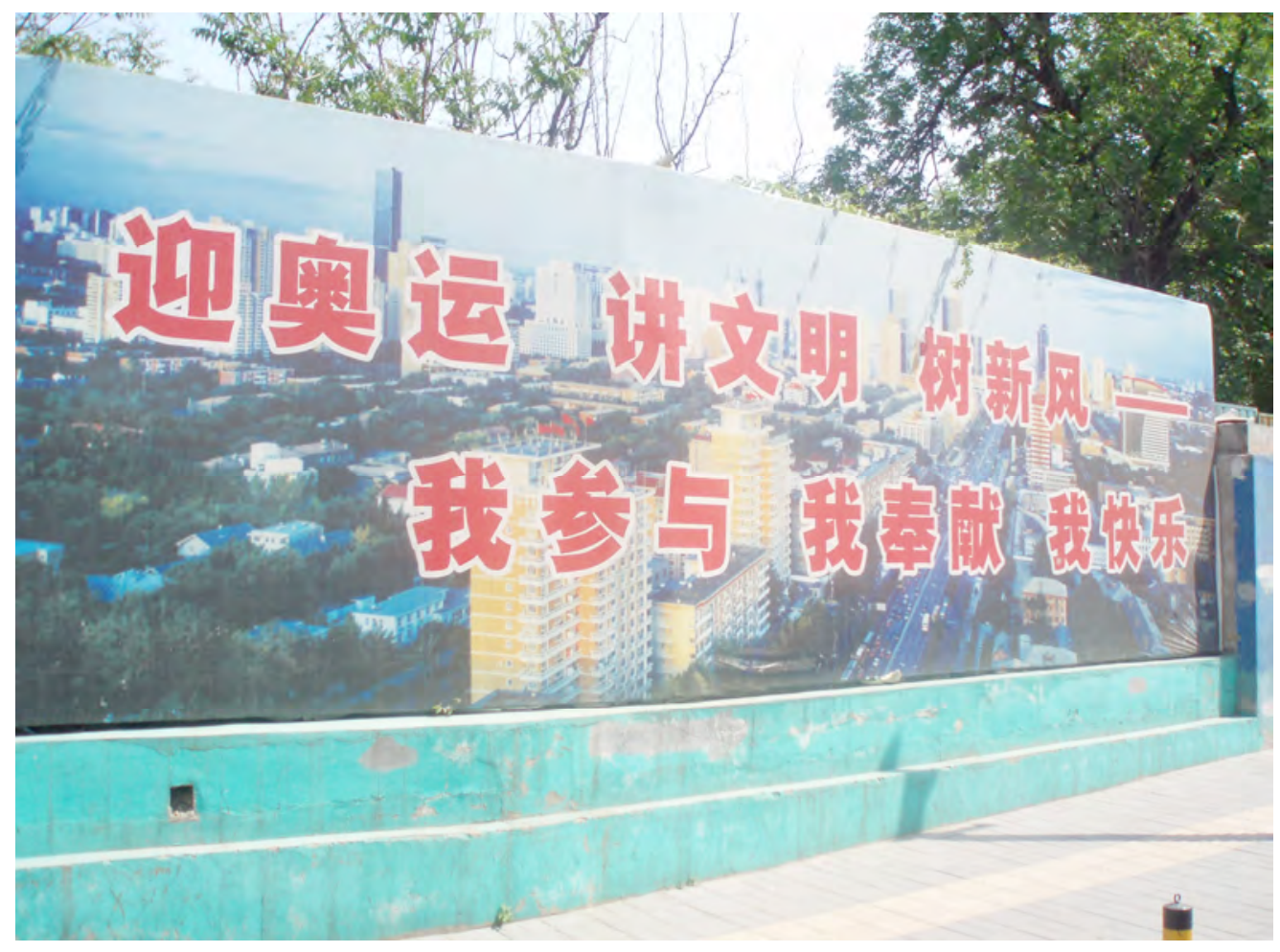

Figure 2: Billboard 'Welcome the Olympic Games-Stress civilisation-Establish new habits.' Beijing, 2008 (C) Maurizio Marinelli

\section{The Olympics: Dream of a strong nation}

From the Summer of 2007 to the Summer of 2008, the streets of Beijing were covered with billboards spreading slogans hailing the imminent Olympic Games. One of the most popular slogans used during the civic political campaign to promote the Olympics was: 'Welcome the Olympic Games_-Stress civilisation—Establish new habits' (ying aoyun, jiang wenming, shu xinfeng 迎奥运、讲文明、树新风). This tripartite motto was meant to have a precise performative effect: the Chinese government expected from its citizens absolute and unflinching support for the Olympics (Landsberger, Kloet, \& Chong 2010; Brady 2009). The 'Games' (in the Chinese sense of youxi 游戏) were 
transmogrified, from the notion of skilled sportive manifestations able to create a spectacle for the viewers' pleasure, to a new geopolitical Great Game-in the climactic sense of the Chinese word yundong 运动—with the final aim of strategically asserting China's primacy in the brave new world of the twenty-first century.

To understand the civic political campaign for the Olympics, it is necessary to inscribe it within the dominant national discourse of 'civilising the citizens.' The starting point was a general idea of citizens' subjectivity, in the Chinese sense of citizens as gongmin 公民—-literally public subjects - allegedly more inclined to perceive themselves as part of a polity, and therefore carrying a stronger sense of 'rules consciousness,' as opposed to a single individual with a developing sense of 'rights consciousness' (Perry 2008). The strategy of promoting 'civilised' (wenming 文明) behaviour and instilling patriotic education in Beijing's citizens has been a dominant trait of the capital's civic political campaigns over the last twenty years, beginning with the campaign to build a 'socialist spiritual civilization' in the 1990s (Landsberger 2004; 2005). Since 2001 the campaign changed tone and the 'new citizenship' campaign took gradual shape. High schools all over China witnessed the introduction of a new mandatory text: A New Citizenship Reader (Yang 2005). This new textbook incorporated notions of citizenship in circulation in official intellectual discourses in the previous two decades, but it also contrasted with previous texts in that it moved away from official ideology, morality or $s u z h i$ 素质 (quality) to focus on civics. The new concept of citizenship embedded in the reader has thus encompassed more civic values, such as civility, tolerance, social trust, liberty, independence, democracy, the 'rule of law' and peaceful development, transmogrifying, without totally abandoning, the 'socialist ethics,' particularly the loyalty to the CCP and love for the people and socialism.

Starting from 2006-2007, the pollination of the Olympics' seeds of patriotic euphoria and national rejuvenation moved one step further: the propaganda apparatus integrated and incorporated all the key elements of the slogans that had been used in the previous historical periods, including the attempt to resurrect the fervour of the revolutionary era, and employing both vertical and horizontal propaganda techniques (Brady 2007). During the 2008 coming out party of the Chinese State on the global stage, previous slogans were reinvented and became part of a thorough and all-encompassing strategy to produce the 'new (civilised) citizen.' The litmus test for the new citizen's proper 
behaviour automatically became the demonstration of an organic and absolute support for the government-led mega-events: this required the enthusiastic upholding of the underlying political rhetoric tropes, aimed at projecting images of 'China's peaceful rise' (zhongguo heping jueqi 中国和平崛起) and the alleged construction of a 'harmonious society' (goujian hexie shehui 构建和谐社会). As Geremie Barmé has poignantly argued, China used the Beijing Olympics as an opportunity 'to tell its story to the world' (2009: 64). At the same time, the Olympics presented an opportunity for the Chinese government to operate a selective re-elaboration of the country's history, and tell its own success story to its public subjects (gongmin 公民). This was demonstrated by the Olympics' opening ceremony, which obliterated any reference to the Maoist era. The Olympics Great Game capitalised on the branding of the built environment, and the Chinese State imposed its carefully constructed patriotic-civilising language onto the cityscape. Those arriving at the Customs checkpoint of the new Beijing Capital International Airport Terminal $3,{ }^{3}$ were greeted by a gigantic, red-hot Great Wall image, accompanied by the words 'Welcome to Beijing!' (Huanying dao Beijing 欢迎到北京). From the airport to the city centre, omnipresent images of the Olympic mascots (fuwa 福娃), ${ }^{4}$ commodified in every shape and form, incessantly and obsessively repeated the slogan: 'New Beijing, Great Olympics' (Xin Beijing, xin aoyun 新北京, 新奥运). ${ }^{5}$

Beijing's urban space was elected as the showcase of a success story of the whole nation, which was proposed, imposed, and exposed by means of a revolutionary-style slogan-like political language, covering images of highrise buildings on large billboards.

\footnotetext{
${ }^{3}$ Terminal 3 was opened in March 2008, with an investment of US $\$ 4.6$ billion and the 'collateral damage' of the forced relocation of ten thousand villagers. It embodies a numeric message of international competition: built in record time (only three and a half years) using 50,000 workers, half a million tonnes of steel and two million tonnes of concrete, Terminal 3 extends for almost three kilometres. It is often compared to Heathrow's Terminal 5 (completed around the same time), but it is six times larger.

${ }^{4}$ Fuwa 福娃 are the friendlies or good luck dolls, whose names are repeated syllables: Beibei 贝贝, Jingjing 晶晶, Huanhuan 欢欢, Yingying 盈盈, and Nini 妮妮. Through the mechanism of Chinese characters' combination, they create the phrase 'Beijing welcomes you' (Beijing huanying $n i$ 北京欢迎你). They are easy to memorize and mimic small children's nicknames. They 'carry a message of friendship and peace — and blessings from China — to children all over the world,' and 'also embody the natural characteristics of four of China's most popular animals - the Fish, the Panda, the Tibetan Antelope, the Swallow - and the Olympic Flame' (http://en.beijing2008.com/37/03/column211990337.shtml). A 100-episodes Olympic-themed cartoon series featuring the Fuwa ('The Fuwa Olympic Cruise' Fuwa Aoyun manyouji 福娃奥运漫游记) was released in China on August 8, 2007.

${ }^{5}$ The literal translation of this slogan in English should have been 'New Beijing, New Olympics.' However, the decision to translate it using 'Great Olympics' instead derived from the Chinese state's perception that the foreign readers might have misinterpreted the use of 'New Olympics' as alluding to the fact that the Olympics needed to be 'renewed.' 'New Beijing, Great Olympics' also became the title of a travelling exhibition, which opened in Sydney in April 2006 and reached Berlin in September 2007.
} 


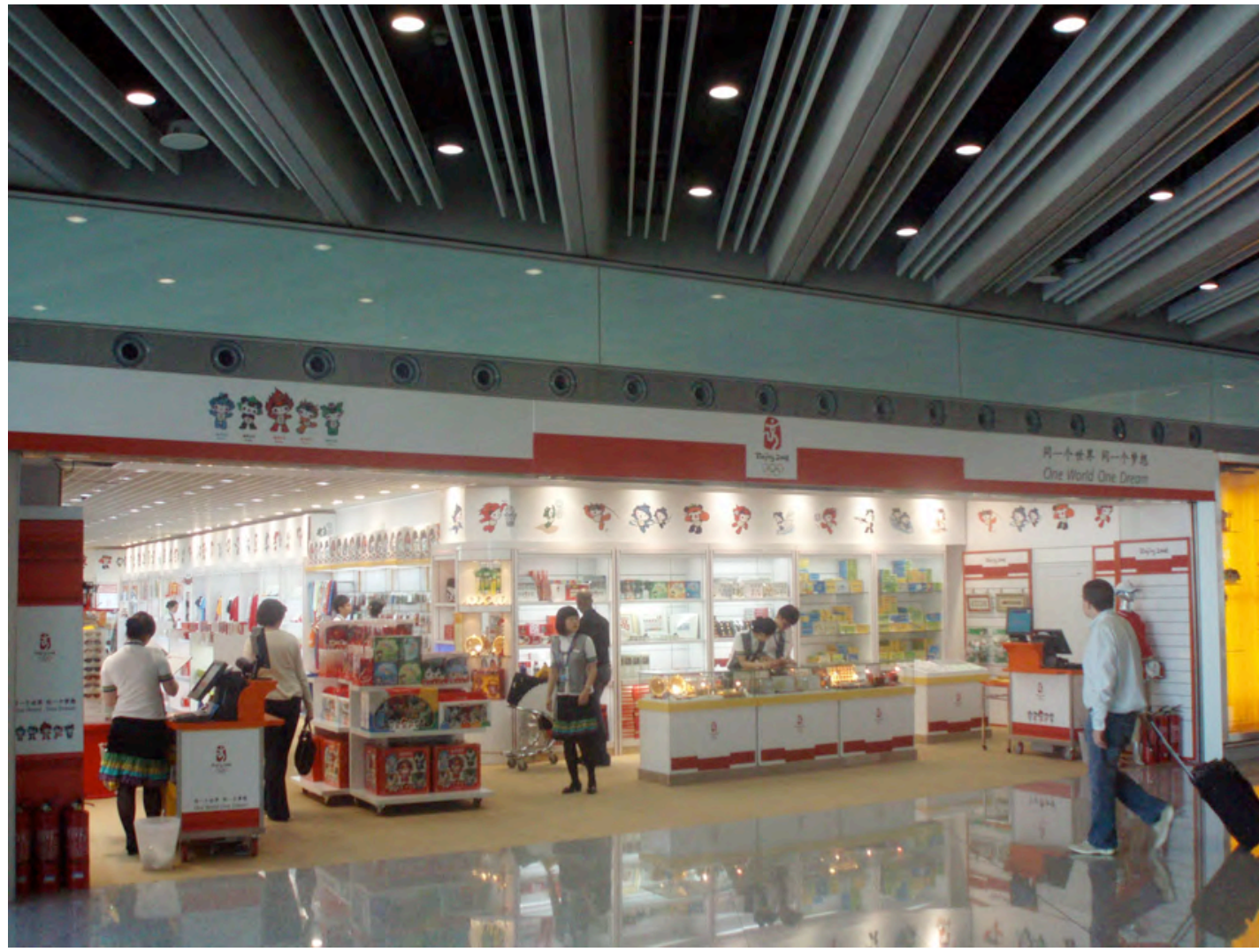

Figure 3: The Olympic mascots (fuwa 福娃). Beijing, 2008 (c) Maurizio Marinelli.

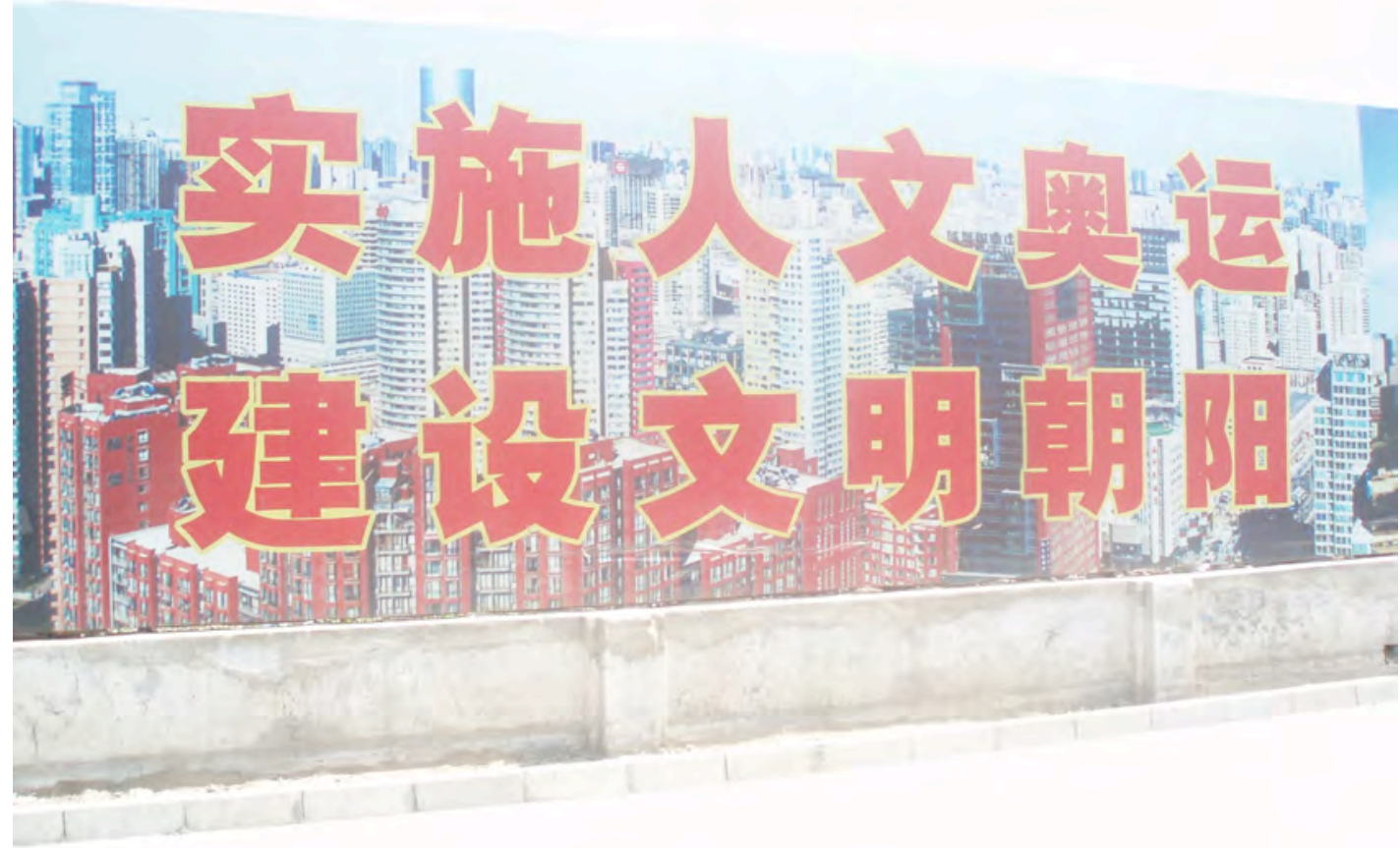

Figure 4: Billboard hailing the 'humanistic' Olympics and the construction of a 'civilised' Chaoyang district in Beijing. Beijing, 2008 (C) Maurizio Marinelli 
This strategy originated also from the CCP's hubristic pride of telling its own story of the world: this was the master narrative of Great Nations that had been carefully rewritten and tactfully 'harmonised.' The popular television series Daguo jueqi 大国崛起 (The Rise of Great Nations), which was shown on China's state network CCTV across twelve episodes on 13-24 November 2006, was crucial to this strategy. Moving away from the previous emphasis on the condemnation of the 'imperialist sin' of the past, when the foreign powers aimed at 'getting rich from the blood of others,' the argument of the TV series was a more positive appraisal of national experiences, in an attempt to represent the 'imperialist sin' of the past as a driving force and a sine qua non for the rise of the 'Great nations' to global status (CCTV 2006, 2007).

The Olympics primarily intended to promote a unified image of national identity. To this aim, the government utilised a marketing campaign of 'en-worldment' (Terkenli 2002): the creation of an urban landscape simultaneously 'encompassing multiple worlds,' in harmony with the Olympics' main slogan 'One world, one dream' - even though the 'outside' worlds were mostly limited to the branded iconic venues created for the Games and the international audience was carefully scrutinised and selected. This spectacle was produced in line with the national master narrative of 'linking up with the international track' (yu guoji jiegui 与国际接轨) (Wang 2007: 1-23). The final aim was to emphasise how China, which had been 'excluded' from the world stage for so long, had finally rejoined the world and self-consciously intended to reposition itself, at the beginning of the twenty-first century, at the centre of the global stage (Wang 2003, 2009). The Olympics claimed to demonstrate that the dream of the strong nation (qiangguomeng 强国梦) (Li 2006) had finally come true, as a sort of self-fulfilling prophecy embodied in Beijing's spectacle. The image of the 'strong China' was based on the following syllogism: since the eyes of the world were now focused on BeijingChina, ergo China had finally regained its well-deserved centrality. However, the China at the 'centre of the world,' the China that wanted to attract the international viewers' gaze and be marveled at, paradoxically embodied the alter ego of a previously well-established, and at least debatable, teleology of modernity that had been proposed and imposed by the Western powers in China's colonial entrepôts in the nineteenth century. The China exposed, imposed and proposed to the rest of the world today seems to have appropriated specific discourses of power and space, which belonged to the West. In the urban settings, these discourses have been articulated through radical 
transformative practices, leading to the deliberate murder of home with physical and psychological implications. The terms coined by Porteous and Smith (Porteous and Smith 2001: 10-23), 'domicide' (the destruction of home) and 'memoricide' (the destruction of historical memory), are particularly suitable to describe what became the norm in urban China's bio-politics of socio-spatial transformation, reflecting hegemonic narratives of progress, rationality, efficiency, forwardness, and globalising 'newness' that are not new.

Against this background, a discussion on the form and content of State propaganda and art, at the time when the capital Beijing became the Olympics' city, requires a particular attention to the 'right to the city' (Lefebvre 1995). David Harvey poignantly interprets Lefebvre's call for 'a transformed and renewed access to urban life' (Lefebvre 1995: 158) adding: 'The right to the city is far more than the individual liberty to access urban resources: it is a right to change ourselves by changing the city. It is, moreover, a common rather than an individual right since this transformation inevitably depends upon the exercise of a collective power to reshape the processes of urbanisation. The freedom to make and remake our cities and ourselves is, I want to argue, one of the most precious yet most neglected of our human rights' (Harvey 2008: 23). In the Chinese context, the discussion of the 'right to change ourselves by changing the city' has to start with an investigation of the politics that produce and frame the official image of the city.

\section{The hegemonic language of the Olympics}

In his work Painting the City Red, Yomi Braester explores the shift in visual practices that accompanied urban material transformation. He uses the concept of urban contract 'to draw attention to a particular power structure' and to investigate 'the complex networks and collaborations' that seem to make possible the creation of 'better cities to engineer better citizens' (Braester 2010: 6). ${ }^{6}$ I argue that language has played a crucial role in this process. During the political campaign for the promotion of the Olympics, the size of the Chinese characters composing the slogans varied considerably, but in all cases the large characters played the dominant role in the billboards, being uncannily juxtaposed to the rendering of a 'modernising' urban landscape that was visible underneath the characters.

\footnotetext{
${ }^{6}$ Braester dedicates particular attention to the 'cinema's mediation between different visions of the city.'
} 
The cityscape's images belonged to Beijing, although some of them could have also been drawn from other generically globalising Chinese metropolises. Fragments of high-rise buildings appeared and disappeared, partially concealed by the characters. In terms of scale, the dimension of the characters, and their relevant visual effect, was overwhelming.

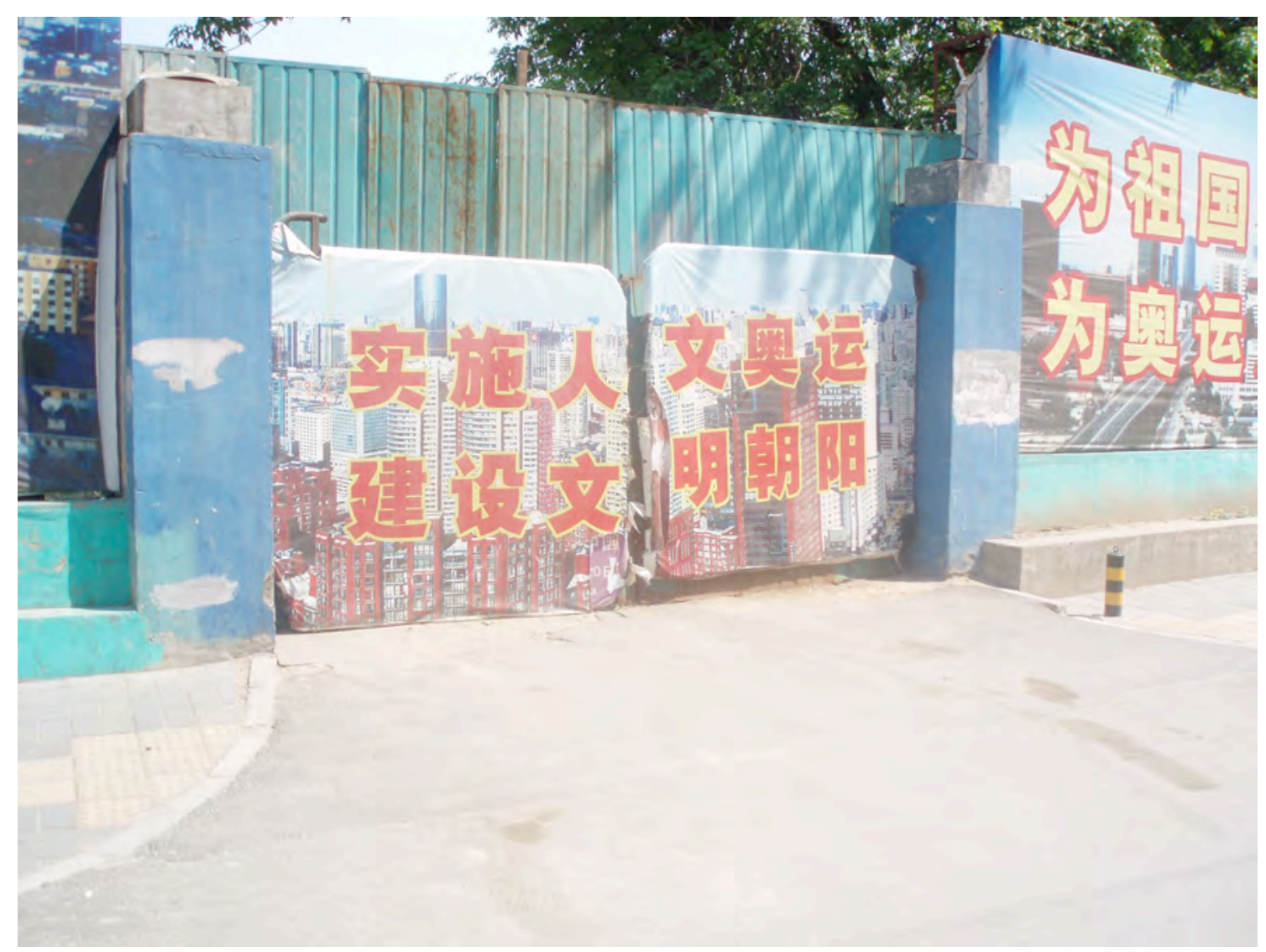

Figure 5: Split billboard juxtaposed to a gate outside a development site. Beijing, 2008 (C) Maurizio Marinelli.

Ultimately, the subject of the campaign was always one and the same: Beijing, the citystage of the 2008 Olympics was the centre stage of national politics. Government power produces reality through 'rituals of truth,' which create specific systems of 'knowledge' (Foucault 1991: 102; 2004; 2007). Beijing became the symbol par excellence of the glorious global destiny of the Chinese nation that, with the Olympics, had finally become an axiomatic 'reality.' The omnipresent slogans asserted that Beijing 'welcomed you,' and the five Olympic mascots repeated this message in unison. In this context, the citizens became part of the normalising force: they both had to internalise the myths, which represented the source of power, and, simultaneously, they were subject to mechanisms of surveillance and reinforcement, which aimed at conforming 
their behavioural patterns to the explicit and implicit rules of the grand design of the State.

Some slogans sang the praise of the 'first class,' the 'civilised' and 'Green Olympics,' others referred to the 'Hi-tech Olympics,' while others emphasised the 'People's Olympics.' Starting from a year before the mega-event, the official version claimed that: 'Celebrating the Games in Beijing in 2008 will afford a unique opportunity to inspire and educate a new generation of Chinese youth with the Olympic values, and to promote the Olympic spirit and the cause of sport in China and the world. ${ }^{7}$ The Olympian dream-come-true was portrayed 'as a catalyst for exchange and harmony between various cultures and peoples. ${ }^{8}$ Across the major intersections and at metro stations, the sensory perception of citizens and visitors alike was bombarded by posters, banners, and giant billboards advertising the 'Civilised Olympics' (wenming aoyun 文明 奥运). The medium conveyed the message of civilised, and ultimately docile, citizens as the sine qua non for the success of the political campaign of the Olympics and, more specifically, required these subjects to sustain, both domestically and internationally, the projective positive image of the nation, which was functional to reassert the legitimacy of the CCP.

Starting from 16 March 2007, a so-called non-profit commercial was continuously broadcast on Beijing Television, showing a schoolgirl who explained in an innocent but proud tone the sea change that occurred in her family after the International Olympic Committee's historic decision: 'My dad is a taxi driver and he is learning English to serve the foreign passengers when Olympics come. My mum is smiling to every customer visiting her counter at the shopping mall. And my granny is making pieces of Olympics craftwork at home!'9 Beijing's taxi drivers were expected not only to learn English, but also to abide by the three crucial civilising maxims: 'Brush your teeth often. Bathe regularly. Change your clothes.' The elimination of foul-smelling cabs was part of the sanitising and civilising campaign (Cho 2007). On the official website, the President of the Beijing Organising Committee for the Olympics (BOCOG) Liu Qi declared: 'It is crucial that the public should strive to desert all uncivilised behaviour,

\footnotetext{
${ }^{7}$ See the official vision of the Olympics at: http://61.135.180.163/eolympic/xay/xay index.htm (Accessed 20 October 2011).

${ }^{8}$ See: http://61.135.180.163/eolympic/xay/xay index.htm (Accessed 20 October 2011).

${ }^{9}$ Blog dated 16 March 2007: http://www.blognow.com.au/beijingsexyfish/55017/Olympic Wenming.html (Accessed 20 October 20011).
} 
and work vigorously toward creating a civilised and harmonious society to host a successful Olympic games. ${ }^{10}$

Following the eruption of violent street protests in Tibet on 14 March 2008, which coincided with the $49^{\text {th }}$ anniversary of the Tibetan uprising of 1959, more 'civilising' slogans were coined. In April 2008, omnipresent red banners associated the Olympics with the patriotic slogan to oppose any Tibetan claim to independence, while at the same time boycotting French goods (ying ouyun, fan zangdu, dizhi fahuo 迎奥运、反藏 独、抵制法货). The internal structure of this slogan, which consists of $3+3+4$ characters, is quite unique: the final four characters reveal the real aim, but they do so in an asymmetric and asynchronous way, unveiling both the problematic coinage and, ultimately, its less civic and more political overtone.

The fundamental binding element of all these slogans was the primary relevance of 'Welcoming the Olympic Games (ying aoyun 迎奥运),' which essentially meant upholding the success story of the nation. The ultimate requirement for the expression of a correct and civilised behaviour was the full embracement of the 'Olympic spirit.' The juxtaposition between this particular kind of language, which was indicative of a precise governmentality discourse, and Beijing's cityscape was strikingly apparent, and did not go unnoticed by Chinese artist Zhang Dali.

\section{The origin of Zhang Dali's 'Slogan Series'}

In his artwork called 'The Slogan Series,' Zhang Dali uses juxtaposition in a unique way, creating in the viewer a twofold effect: a sense of aesthetic hyperbole and emotional-psychological claustrophobia. In some ways, this reaction is a projection of the artist's response itself to the paradoxes of the civic political campaign to promote 'the Olympic spirit' via civilising the citizens. From that evening in August 2007, when Zhang reflected on the 'Same world-Same dream' slogan that he saw on the fourth ring road, the artist started taking more and more photographs of civic political slogans. He selected the following slogans from the myriad that were plastered on large billboards in the streets of Beijing in 2007 and 2008:

\footnotetext{
${ }^{10}$ See: http://en.beijing2008.cn/ (Accessed 20 October 2011).
} 
'Seek the truth and be pragmatic. Open up to innovation. Promote the balanced development of the three cultures.'

'Study ceremony and propriety and you will make yourself more cultivated. Behave according to ceremony and propriety and you will make (your) life more beautiful.'

'Enhance an advanced culture. Promote the social development.'

'Take to heart the study, the implementation, and the fulfilment of the spirit of the Party's Seventeenth Congress. Push forward the construction of the harmonious socialist society.'

'Strengthen the construction of morality in the way of thinking. Elevate the cultural quality of the citizens.'
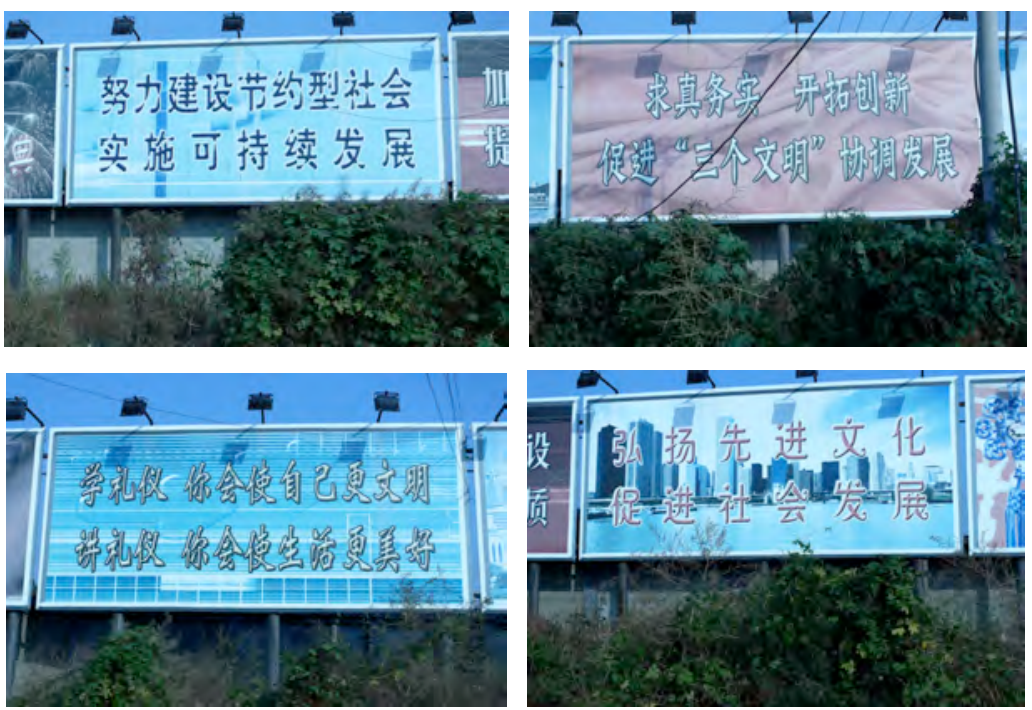

Figure 6: Billboards in the streets of Beijing in 2007-2008 (C) Maurizio Marinelli.

In Zhang's artwork, the slogans are juxtaposed with images of human faces that are also deriving from photographs. The human faces are those of common people. Zhang Dali was buying rejected passport-size photos from photographers' studios. These photos essentially carry an ephemeral connotation: they capture a moment in time that is markedly brief, they are meant to serve a precise function since they are meant to be used for passports, ID cards, etc. The 'life' of these photographs is metaphorically protracted by the photographer's decision to keep a copy of them for a little bit longer, just in case the clients needed a reproduction. After a while, the photographer puts them all together in a plastic bag and throws them away. Zhang's decision to purchase them, somehow further extends the life of these photographs. The artist buys these bags of mixed photographs of common people, and then selects some of them, based on the light, or on the position of the face. Zhang uses a technique similar to pointillism to provide the opportunity to these human faces to re-emerge, and not be forgotten. The texts are actually creating the images, since the Chinese characters, which repeat the 
civic political slogans photographed on the streets, are painted by brushstrokes in different tonalities of color so as to produce portraits of anonymous individuals. The results are highly stylised, formal portraits of nameless men and women, posing for the first time for the camera, and here again, unconsciously repeating that pose through the artwork. They seem to be looking the viewers straight in the eyes, challenging them to distinguish between the human images and the series of phrases that are juxtaposed with them. In one sense, the human faces are objectified by the slogans, now that they are artistically reproduced. Almost mechanically the original individuals seem to regain, but then actually lose their identity. They are branded by the Chinese characters: supersigns of their State-sponsored Chineseness (zhongguoxing 中国性) (Yang 1998). ${ }^{11}$ This is a clear indication that individuals cannot escape the official civic political discourse, since they intrinsically belong to the Chinese State and are subject to its propaganda. Zhang explains: 'People's experiences and thoughts are formed by the world they live in, and the "Slogan Series" draws attention to the influence that external forces exert on society, and to the circumstances of people subjected to those forces' (Zhang 2008b). However, Zhang's artworks could also be interpreted as a demonstration of how the constative (embodied by the grammar of State propaganda) is pushed away by the performative (the grammar of artistic resistance), since the artist's text-images allow the viewers new possibilities for seeing and speaking back. But does this offer a way out, or is it more a denunciation of the importance to resist the subservient acceptance of hegemonic language, and develop awareness to oppose collective amnesia?

There is another important element in the juxtaposition of slogans and human images. If it is true that the artworks offer a second life to the photographs that had been taken in a lively moment and then discarded, once the Chinese political characters are juxtaposed with the portraits, the expressions of these individuals change and they look more like dead people. That unique moment in time of the pose in the photographer's studio, charged with emotions and potential beauty, is gone forever. The Chinese characters recreate the humans but their semblance of normality has disappeared: these human faces appear ghost like. By so doing, Zhang's artwork unmasks the risk of collective

\footnotetext{
${ }^{11}$ Chinese poet Yang Lian, in his poignant discussion on 'Chineseness' emphasizes the distinction between two terms: the Chineseness as State (Zhongguoxing 中国性) and the Chineseness as language (Zhongwenxing 中文性). Zhongguoxing 中国性 indicates the Chinese culture as a State-sponsored ideology, a socio-political entity functional to the creation of a prescriptive form of 'correct' citizenship via a codified schemata of culture-language. Zhongwenxing 中文性 indicates the possibility to build a personal Chinese culture via the search for a personal language.
} 
amnesia of the minds of the citizens to the techniques of governmentality that are embedded in the dominant political language, and are ultimately meant to produce 'civilised' and 'harmonized' docile bodies. Zhang's intentional juxtaposition invokes the necessity to reflect on the internal paradoxes that lie behind the repeated use of political formulations ( $t i f a$ 提法) (Schoenhals 1992: 6-29). He seems to invite the viewer to delve more deeply into the archaeology of knowledge-power (Foucault 2002) that characterises the campaign to 'civilise the citizens': with a critically inquiring mind in an attempt to disclose the ways in which the language of power is manufactured, articulated and performed according to a 'ritual of truth.' The relationship between the language and the discursive formations creates a space of order, where a system of knowledge is constituted, proposed and imposed. However, even dissecting Zhang's

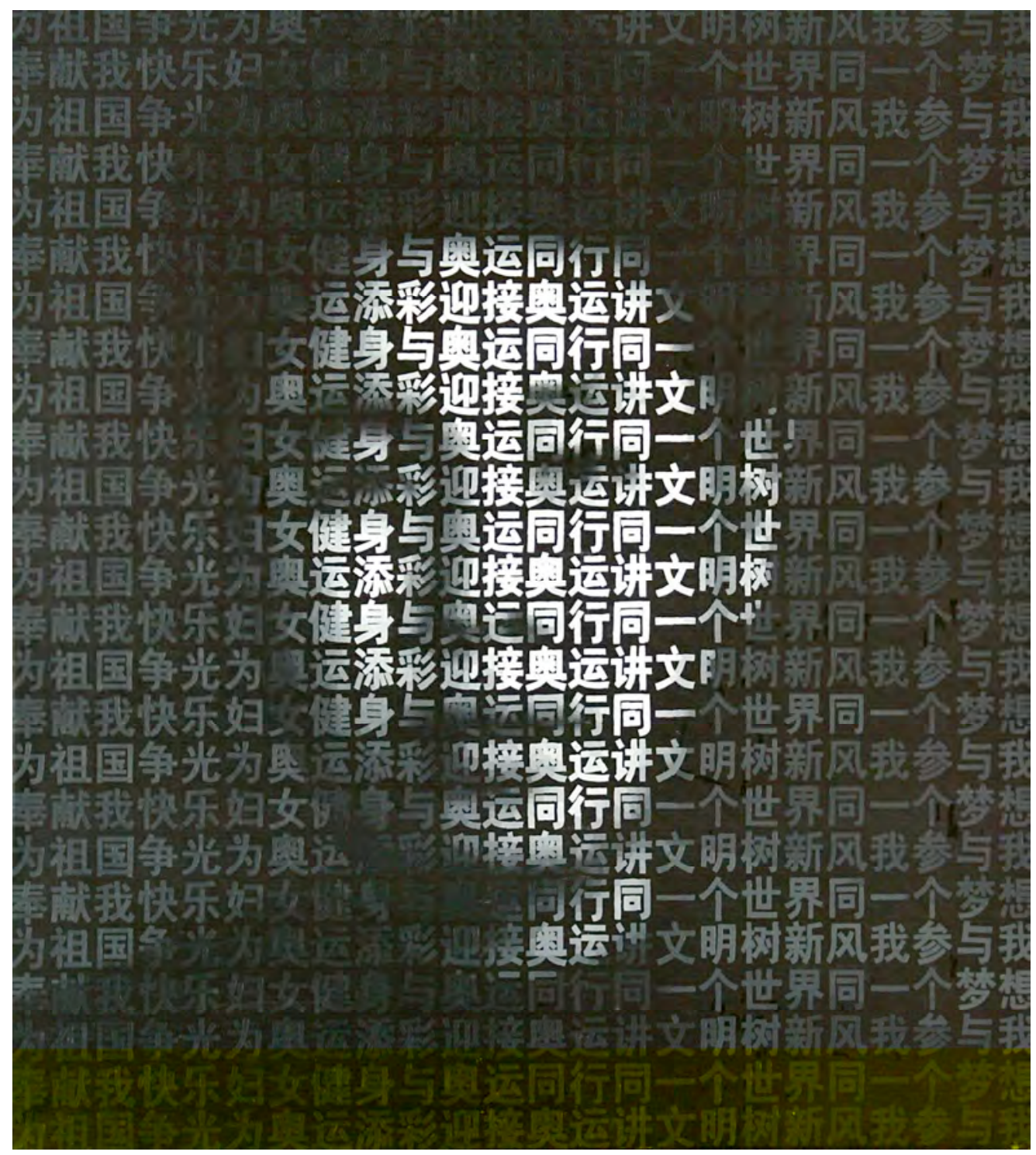

Figure 7: Zhang Dali, Slogan No. A6, 'One world—One dream,' 180 x 200 cm, 20082007 (C) Zhang Dali.. 
artwork, reading aloud the characters, both horizontally and vertically, does not 'make sense.' It does not allow the viewers to 'save' the human beings compressed behind them, although it partially allows them to decipher the traces, and to grasp the implicit rules that dominate civic political language and frame the map of the world around us. The scope of language is strictly related to the 'capillary form of existence' of political power. In Foucault's words, there is a point in which power 'reaches into the very grain of individuals, touches their bodies and inserts itself into their actions and attitudes, their discourses, learning processes and everyday lives' (Foucault 1980: 30). This specific point seems to be embodied in Zhang's 'Slogan Series' artwork: it is a point of no return. The artist elaborates on photographs to shed light on an epistemic space, and in this way reveals both the continuity of the language-power hegemony across time, and the possible discontinuities of the human condition, between past, present and possible future awareness. This is crucial to Zhang's struggle against collective amnesia, conducted through his photography-based artwork.

\section{Text-images: The violence of language}

As Susan Sontag poignantly argued, 'Photographs really are experience captured, and the camera is the ideal arm of consciousness in its acquisitive mood' (Sontag 1977: 3-4). It is an act of appropriation that responds to a visual elicitation associated with a sensorial solicitation. Therefore, picture-taking creates a triangular relation between the photographer and his experience of the world 'that feels like knowledge -and, therefore, like power.' Sontag adds: 'A photograph is not just the result of an encounter between an event and a photographer; picture-taking is an event in itself, and one with ever more peremptory rights - to interfere with, to invade, or to ignore whatever is going on' (1977: 11). Picture-taking has always been an essential part of Zhang's artistic creation, as demonstrated by his 1990s graffiti artwork (Marinelli 2004), and his meticulous study of the doctored photographs (Zhang 2006). One could argue that, for Zhang, photographing an event is strictly connected with his 'sense of situation ... articulated by the camera's intervention' and this is integral to his 'ethics of seeing' (Sontag 1977: $3)$. But what is the relationship between images and texts?

Michel Foucault, in his study on Magritte's Ceci n'est pas une pipe, argued that images and texts are antagonistic semiotic systems (Foucault 1973). Therefore, they cannot coexist in a single work since one would always try to subdue the other. However, in 
China, during the Maoist era (1949-1976), images and texts effectively coexisted, to the extent that the text framed the ritual of truth of a claimed reality (Apter \& Saich 1994; Ji 2004; Marinelli 2009). In Mao's China, the slogans effectively set the boundaries of linguistic expression, within the framework of a skilfully constructed epistemological and ontological universe. In the Chinese historical tradition, the 'correctness' of language has always been considered a source of moral authority, official legitimacy and political stability. Political language has always had an intrinsic instrumental value, since language control is the most suitable way to convey and maintain the orthodox State ideology. Formalised language has also functioned as a powerful means to

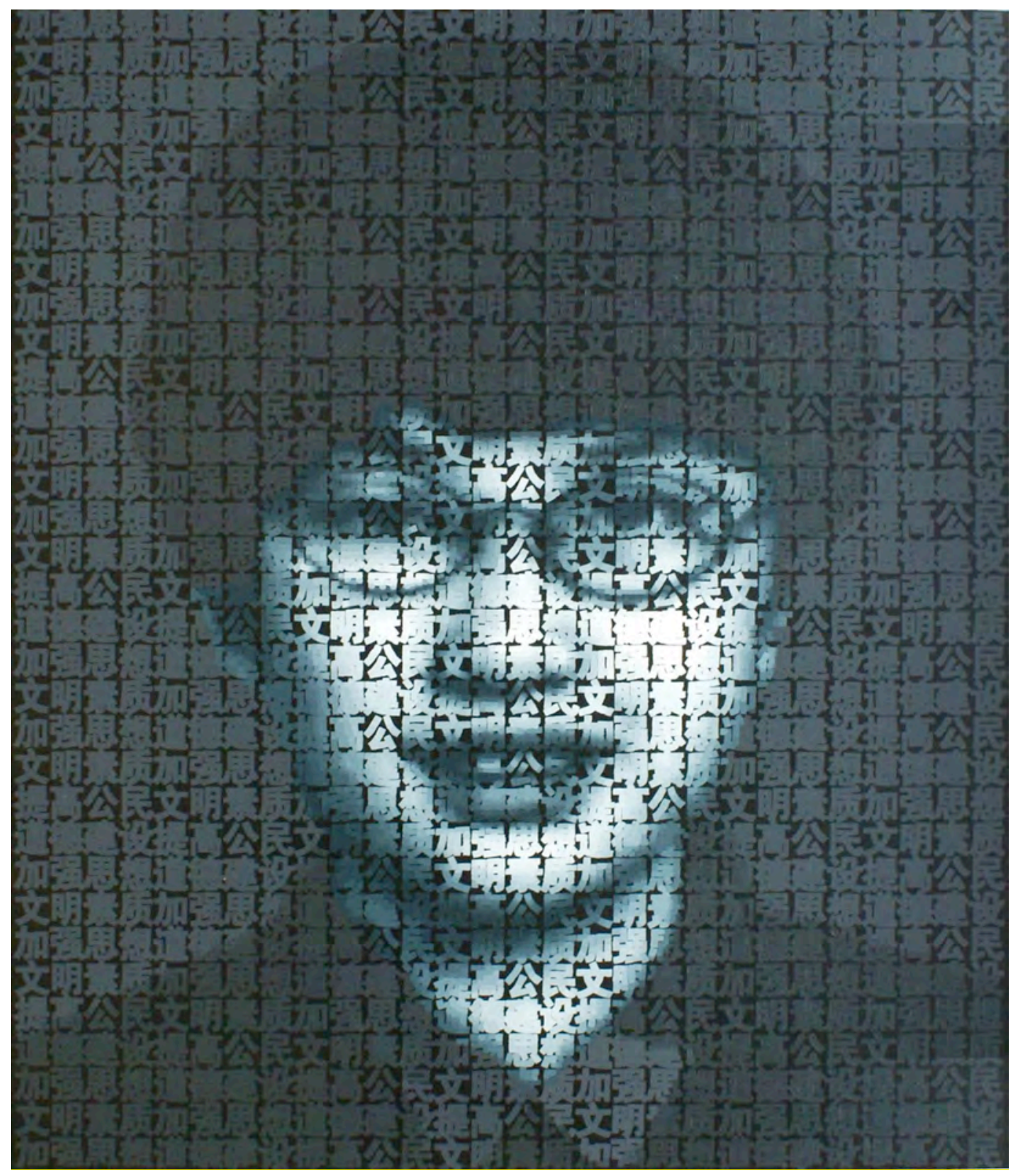

Figure 8: Zhang Dali, Slogan No. 6, 'Strengthen the construction of moral thought,' $182 \times 223 \mathrm{~cm}, 2007$ (C) Zhang Dali. 
standardise the range of expressiveness of the subjects. Wittgenstein argues that words have the power to set the limit for the 'expression of thoughts,' because the boundaries of language indicate the boundaries of one's own world: 'It will therefore only be in language that the limit can be set, and what lies on the other side of the limit will simply be nonsense' (Wittgenstein 1961: 5-6).

In Zhang's 'text-images" ${ }^{\text {, }}$ something unique happens. There is indeed a sequence of characters that generates a text, but that text has a physical, emotional and psychological resonance. As noticed by Stephanie Bailey: it 'creates a dizzying effect that evokes spinning, hypnotism, radars, targets, and magnetic fields' (2011: 99). The repetition of the Chinese characters creates a tight and claustrophobic grid that imprisons the portrait of the human face. The characters cannibalise the individual's somatic traits. The viewer has to engage into a physiognomic exercise to detect the human features of these persons and cannot be immune from their psychological discomfort.

There is a strong element of violence in these paintings. Violence is a common trait to Zhang's work. But here the violence of state propaganda is appropriated by the artist to produce quite a different message. Zhang's artwork brings to mind Lu Xun's image of 'man-eating-man' that dominates the ending of the 'Diary of a Madman' (Kuangren riji 狂人日记) (Lu Xun 1918: I, 422-33). Looking at Zhang's large paintings showing human faces covered by repeated political slogans, one could say that the characters are eating these young men and women alive, corrupting their soul by denying any possible claim to prolong their existence as they originally were, and ultimately negating their opportunity to find a language to express their 'right to the city.' The artist launches his call to arms, perhaps hoping that somebody will hear and 'save' the human beings portrayed here from oblivion, oppressed as they are under the burden of civic political propaganda. Heidegger argues that 'Language speaks man,' in the sense that language pre-exists man, and man could not exist without language. The idea that language is the creator of human consciousness leads Heidegger to conclude that only language manifests the perceptible traits of things of the world (Ereignis, meaning 'appropriation'). Language, therefore, is the facilitator of thoughtful perception. In other words, language must be considered as the progenitor of thoughtful perception: the

\footnotetext{
${ }^{12}$ This expression is more accurate, since the most basic unit of word structure in Chinese grammar is the morpheme, which is the smallest combination of meaning and phonetic sound.
} 
internalisation of outside reality in the mind. But when language becomes ossified, when formalised language is repeated ad infinitum - although emptied of any relevance and any resonance-language ceases to originate thoughtful perception and, in that sense, language ends up not speaking man, but eating man.

At the same time, to continue paraphrasing Lu Xun, one could also say that Zhang's work on the interplay between political language and the violence of the city, indicates that 'A Road is made' (Lu Xun 1956: I, 75; 1921: I, 485): the road here points at the uncanniness of a language that clearly embodies a Chinese element (Yang 1998), but does not express the 'right to the city' for the human beings that are phagocytised by it. The human faces seem to struggle to emerge, compressed as they are by the Chinese characters which obscure their somatic traits and tend to annihilate their subjectivity, by branding them with repeated civic political propaganda lines.

From the very beginning, Zhang's artwork carried a powerful iconoclastic connotation, striving to create a dialogue with the violence of urban destruction. In the year 2000, Zhang began the first AK-47 Series covering similar human faces with the tag of the Soviet assault weapon AK-47. He had used this war-signifier for the first time in the 1990s, in 'The Dialogue Series,' spraying the AK-47 tag on the walls of Beijing that were doomed to be torn down (Marinelli 2004). He was shooting, using spray-paint and hammer instead of a real gun, AK-47 to represent the violence (baoli 暴力) of a community being ripped apart: 'If I use this name, I make people think about the Third World, the violence of the cities, and the wild hooligan culture. That's not what people want to think about in Beijing today!' (cited in Marinelli 2004: 436). AK-47 was a powerful way to draw attention to the destructive violence assaulting the city of Beijing and their inhabitants: in Beijing, during the last twenty years, thousands of old buildings have been erased at a pace faster than that of wartime Berlin and London, hundreds of thousands of people had to be relocated, while millions of migrant workers have entered the city. Zhang is also exposing a dialectic war of signifier (the sound-image AK-47) and signified (the violence of the city and in the city), a war of style (the repeated slogans) and content. In his new artwork, which is often referred to as 'The Slogan Series,' Zhang seems to indicate that violence is embodied in the Chinese characters themselves, in a language that is omnipresent and charged with an aura of political 
authority, associated with a claimed reality and the construction a specific 'ritual of truth.'

\section{The time/s of the city and 'the people'}

Zhang's painting technique allows for the human faces to emerge from the different tonalities of the brushstrokes of colours. Therefore, the characters somehow precede the images, lead up to them, but they also appear as if they were inside the images. Texts and images once again coexist: they are so intertwined as to become indivisible. Apparently, the characters conceal the human faces. Although they recreate them, they also make them lose their identity. But ultimately, what is lost is the sequential and logical meaning of these words. They become words-non-words, echoing the way in which the material transformation of the city generates a place-non-place, an uncanny universe of different truths, different spatialities and temporalities, where the individuals struggle to find an appropriate language to express, symbolically, their right to the city.

In a personal conversation with the artist, in the Spring of 2008, Zhang Dali was reflecting on the multiple ways in which the Olympics' construction projects ultimately revealed the multiple temporalities of China's multiple layers of presents. First, there is the futuristic present, exemplified by the glittering internationally branded and aweinspiring Olympic Games' venues: this temporality indicates China's aspiration to the new-new and the ultra-postmodern era. However, the positionality of the branded venues on the same locale where other buildings previously existed is a reminder of the erasure from memory of the hundreds of thousands of dwellers who have been forcibly removed (chaiqian 拆迁). This is the second layer: the present-pastness that had to be annihilated in the name of progress, forwardness and the claimed logic of the biopolitics of modernity. The third layer is the present-present, which is characterised by a contrasting time: the rhythm of the lives of the migrant workers, who have been the real craftsmen of the ultra-celebrated Olympic Games' infrastructure and the iconic buildings.

Understanding these processes requires an investigation of the "currents of contemporaneity': only the exploration of multiple and processual modernities will allow us 'to grasp the complexities of the present' (Smith 2008: 35). Modernity indicates a division of the world between the old and the new, the past and the present, 
while contemporaneity indicates the coexistence of conditions, the coexistence of spatialities in the presentness of the cityscape.Walking in the streets of Beijing in the year before the Olympics, one could see, right next to the emerging iconic venues, hundreds of migrants working 24/7 shifts and sleeping only a few hours in dust-covered sleeping-berths, precariously assembled on the street pavements: here lived the migrants, and here their possible dreams took shape. Their dreams were most certainly alien to the Olympics' grandeur, but here they were; partially protected by a ripped tarpaulin, but ultimately exposed. One might wonder if the Olympics' civic political 'civilising' campaign had these migrants in mind. More likely, they were not even meant to be seen: in fact, their permits to stay in Beijing were revoked at the beginning of the summer of 2008 (Broudehoux 2008). But until then the migrants were everywhere: inside and nearby the iconic building sites, working on the train tracks of the new 'harmony trains (hexiehao 和谐号)' leading to and from Beijing Railway stations to some of the other six cities hosting specific Olympic events. ${ }^{13}$

Beijing is a city that resists being framed. Paraphrasing Walter Benjamin, one could define it as a site of ruin (Benjamin 2000). Zhang's artwork invites the viewer to see beyond the allegorical gaze, since the city that on the eve of the Olympics was depicted as the triumph of national hubris and long-standing civilisation, is also the city where many can experience estrangement, alienation and spatial-psychological displacement. Beijing has become an uncanny space. The civic political campaign is supposed to provide behavioural guidance to the 'new citizens.' Zhang defines the slogans as 'the parents of the people.' He observes that the slogans are omnipresent, from the government documents to the public space, with the function of 'teaching us what we have to do, just like parents teach a young pupil.' He argues that the incessant reproduction of slogans seems to have generated a collective anesthesia: 'the citizens watch them but do not really see them.' This is the reason why Zhang decided to juxtapose people with slogans. The history of Zhang's artwork on slogans indicates a progressive awareness: the slogans 'are adjacent to our bodies (zai wo shenbian 在我身 边), 'they fill and dominate our physical space: 'from every point of view, they guide our actions (zuowei 作为) and our way of thinking (siwei fangshi 思维方式). ${ }^{14}$ They

\footnotetext{
${ }^{13}$ Qinhuangdao, Shanghai, Shenyang and Tianjin hosted the football competition. Qingdao hosted the Olympic Sailing regatta. Hong Kong hosted the equestrian events.

${ }^{14}$ Personal interview with the artist, July 2011.
} 
often carry a stern or imperative tone, using adverbs like 'resolutely' (jianjue 坚决) or auxiliary verbs like 'must, have to' (bixu 必须), or expressions such as 'absolutely must.' Zhang argues that these slogans 'sound like a severe father who is educating his child who has not yet come of age (wei chengniande haizi 未成年的孩子), to the extent of telling him what he has to do. ${ }^{15}$ These slogans also carry an emotive capital: they demystify the fear and the sense of insecurity, which derive from alienation and displacement, by projecting a firm image of stability and civility. They are evidence of the decision of the State to be seen. They are the sign of policing the public space in the name of 'civility' and, ultimately, requiring the 'new citizens,' exemplified by the 70,000 Olympics' volunteer, to sing in unison 'we are ready' (zhunbeihaole 准备好了), ${ }^{16}$ and contribute to the success of the Olympics' spectacle. In Zhang Dali's words: the slogans are meant to be 'telling and educating us, telling the people (renmin 人民) how we should think and how we should behave,' as if 'we, the people, were unable to reach a level of maturity (chengnian 成年) ... we were continuously making mistakes, our thoughts were naïve, we were unable to understand how to live properly. ${ }^{17}$

In this sense, Zhang's work prefigures the main theme of the famous novel 盛世中国 (The Fat Years 2011) by Shanghai born, Hong Kong raised, and long term Beijing resident, Chan Koonchung. Chan's political satire focuses on how hegemonic power can manufacture 'reality' and induce a feeling of sustained happiness and well being among its subjects (Barmé 2011). ${ }^{18}$ In a hypothetical China, in the year 2013, most of its citizens are happy and content, enjoying their good fortune to live in an 'Epoch of prosperity,' while having no memory of the past hardships. But there is something sinister in this widespread cheerfulness and complete collective amnesia. A small number of individuals have the feeling that something strategically premeditated took place: in 2009 the Chinese Leviathan decided to delete a whole month from the public memory to argue that the beginning of the Global Financial Crisis (GFC) coincided with the beginning of China's Golden Age of Ascendency. This small group of out-ofsync, strangely 'unhappy' souls are determined to solve the riddle of the political

\footnotetext{
${ }^{15}$ Personal interview with the artist, July 2011.

16 'We are ready' was the theme song for the celebration of the Beijing 2008 Olympic Games one-year countdown. It was sung by 100 Chinese singers in Tian'anmen Square on 8 August 2007, to exemplify the motto 'I participate, I contribute, and I enjoy.' It can be seen on Youtube:

http://www.youtube.com/watch?v=Soxk0e9ZjKI (Accessed on 3 March 2012).

${ }^{17}$ Personal interview with the artist, July 2011.

${ }^{18}$ Barmé s special issue of China Heritage Quarterly on 'China's Prosperous Age' (2011) offers the most complete analysis of the novel and its scope.
} 
mystery that lies behind the New Prosperity Policy, and discover what happened to that month and why everybody else seems to be so happy. The CCP Propaganda

Department has intentionally rewritten the past to suit its present interests and lead the Chinese people to believe that they now live in 'le meilleur des mondes possibles' thanks also to the CCP's semi-divine character being simultaneously omnibenevolent, omnipotent and omniscient. Chan Koonchung, in an interview, reminds us of the famous Tang dynasty's songstress Jiang Shu, who was able to sing two songs simultaneously through her mouth. This kind of super-natural ability is necessary today to fill what he sees as a wide 'perception gap between the idea of China and the reality on the ground.' Chan explains that the inspiration to write this novel derived from a poster that he saw in a post office in Beijing, with the characters Shengshi huadan (盛 世华诞) to celebrate the 'prosperous' 60 years of achievements of the PRC. Chan emphasises that the so-called 'prosperity' is also built on 'the harsh exploitation of the farmers-workers' and 'repression' (Goldkorn 2010). In the last few years, the message of China's Gilded Age has been sung loud and clear by the CCP, especially with the 2008 Beijing Olympics, with the 2010 Shanghai World Expo, and again in 2011 with the celebration of the Party's ninetieth anniversary. The message is that China has reached a new stage of prosperity and surpassed many developed countries.

\section{The right to the city as political ideal?}

Zhang Dali's work is characterised by a strong critical aestheticism that points in the direction of defending the 'right to a language' to inhabit the city. In his analysis of the 'accumulation by dispossession,' that dominates the hegemonic liberal and neoliberal market logics, David Harvey engages with the global struggle on the urban question since 'the metropolis is now the point of massive collision' between the affluents' colonisation of enclaves and the undeserving poor. As a way to unify the relevant crises that 'repeatedly erupt around urbanization both locally and globally,' Harvey suggests adopting 'the right to the city as both a working slogan and political ideal, precisely because it focuses on the question of who commands the necessary connection between urbanization and surplus production and use' (2008: 7). Harvey's argument for the 'right to the city' as a new and fundamental type of human right is based on his discernment of the fallacy of the political economic imperatives of global capitalism and, in the Chinese case, of 'the hegemonic command of capital and the state' (2008: 7). 
In a context more connected with the aesthetic realm, but nevertheless ultimately committed to the search for a critical way to contrast this hegemonic command that has led to indiscriminate urban destruction, Zhang's artwork can be interpreted as a 'call to arms' for ways of challenging the strategy of presenting the city as a unified whole (De Certeau 1984). Zhang's powerful juxtaposition of texts and human images echoes Harvey's argument, since they both claim a democratisation of the 'right to the city.' In Zhang's case, he asserts the right of the people to break away from an ossified and formalised language, since this is the sine qua non to be able to express multiple opportunities of walking in the city. Like the Decerteausian walker at street level, Zhang's portraits seem to struggle to overcome the fixity of their pose and the prepared look on their faces.

These human beings seem to strive to break through the overwhelming sense of oppression imposed by the slogans, as if they intended to set themselves free, escaping from the imposed textual grid and advocating their right to a language that allowed them to move in ways that are not fully determined by the plans of the organising body politics. Zhang's work concretely illustrates De Certeau's argument that everyday life works by a process of encroaching on the territory of others, using the rules and products that already exist in that culture in a way that is influenced, but never wholly determined, by those rules and products. In his short but incisive artistic statement on 'The Slogan Painting Series,' the artist insists on the intimate relation between all his artwork and 'the real society (shehui xianshi 社会现实)': 'Reality is the spiritual force and the origin of my creative work' (Zhang 2008a). The adjective 'real' and/or the noun 'reality' appear eight times, reflecting the artist's concern with finding a way to relate to the 'real': 'With regard to the relation between reality and symbols, I cannot indulge in a fantastic world. What I have at heart is the reality: the description of reality is the crucial issue in all my artwork.' In his previous work called 'A New History,' on the alteration of photography and images for political purposes, Zhang Dali had reflected on the layers of reality and the complicated attempts to distinguish 'the real' from 'the fake.' The reflection on the real takes Zhang Dali in the direction of drawing a parallel between his previous artwork on the war-signifier AK-47 (the tag that he had also used to cover human faces in his paintings made in the year 2000) and the 'Slogan Series,' concluding that 'the slogans are now substituting the former weapon's name' (Zhang 2008a). 


\section{Conclusion}

This article analyses the relationship between State propaganda and art, through a detailed study of Zhang Dali's text-images entitled 'The Slogan Series.' It also sheds light on the artist's relationship with the city where he lives, investigating Zhang's provocative response to the State's linguistic engineering to produce 'civilised citizens.'

Throughout the 1990s, the history of Beijing had been re-written to annihilate the image of the desecrated city, covered with the bloodshed that tainted the political capital on June 4, 1989. Beijing was progressively recast into an international stage city. The newly imposed glittering image reached its climax on the eve of the 2008 Olympic Games. However, there was something that architecture and infrastructural projects could not obtain by themselves. The renegotiation of Beijing's identity as an international metropolis had to be matched by the production of the 'correct' image of new citizens. These two intertwined discourses became fundamental strategic components of the CCP's agenda, and have become particularly crucial to the $\mathrm{Hu}$ Jintao-Wen Jiabao regime's articulation of the master narrative of China's 'Harmonious epoch of prosperity (hexie shengshi 和谐盛世).'

Beijing's success story was initially constructed on the basis of two pillars: urban renewal and commercial redevelopment programmes. However, the production of space (Lefebvre 1991) continues to reveal that there was a gap to fill: both Beijing's local residents (Beijingren 北京人) and the outsiders (waidiren 外地人) alike were not deemed to be the appropriate agents of this newly imagined and constructed society of spectacle (Debord 1967). A fundamental necessity emerged: the reinvention of Beijing and its urban aestheticisation as dominant components of the municipal political discourse, could not be separated from a systematic programme of civic political education, with the aim of instructing the public subjects to behave according to precise hygienic norms and a sanitised system of values and civility, which ultimately would have reinforced their patriotism. This is the reason why, on the eve of the Olympics, the three main components of the dominant rhetoric of Beijing as a modernised international metropolis progressively became: 1) beautification of the physical environment; 2) civilising reforms; and 3) social disciplining.

Zhang Dali's artwork originates from his dual intention to problematise what happened to the 'real society' in the city where he lives and, at the same time, to bridge the gap 
between art and 'real' space. On the eve of the Olympics, Beijing's cityscape was officially promoted via the spectacle of branded sport venues and iconic buildings. ${ }^{19}$ The architecture of a city is essential to its identity: the city is a sort of museum without walls. Walking through the built environment every day we build the city a second time, so that it exists both physically around us and virtually in our memories. Therefore, the destruction of the dominant architecture has devastating effects on the identity of the place and the individuals who call it home. Zhang Dali's previous artwork, and in particular 'The Dialogue Series,' had called the attention of the viewers to the human dimension of the deliberate domicide and memoricide that has occurred in Beijing. However, with the preparation for the celebration of the Olympics something apparently 'new' happened: the Chinese government saw an opportunity to move the campaign to 'civilise the citizens' to a higher level. Actually, this is not new. In the late nineteenth and early twentieth centuries, for example, the British colonial power in Kolkata, before the capital was moved to Delhi in 1911, had used the grand architecture to inspire awe in the natives and progressively transform them into docile bodies. In a similar fashion, the Chinese government used an inversionary discourse of language and power. The 'civilising the citizens' campaign went hand in hand with the branded architecture of the Olympics. Civic political language has been used as the tactical instrument to produce a collective amnesia, with the aim of inspiring awe in the international arena for the economic triumph of China in the celebrated 'new Asian century' and, at the same time, make the domestic audience proud of China's prosperous present-future (Chan 2011).

Zhang Dali's 'Slogan Series' appropriates the slogans of State propaganda, repeats them ad infinitum and juxtaposes them with portraits of common people. Thus, the artist demystifies China's awe-inspiring story, and opens a new space to explore the possibility of speaking in different tongues.

\section{Acknowledgements}

My grateful thanks to the anonymous peer-reviewers who offered helpful comments for the revision of this article. I would also like to thank Dr Patrizia Galli, for her careful reading with suggestions, and Zhang Dali for his thought-provoking work, and the stimulating conversations that I had with both of them in Beijing.

\footnotetext{
${ }^{19}$ On the importance of the spectacle as 'social relation between people that is mediated by images' as opposed to a mere collection of images, see Debord (1995: 12).
} 


\section{Reference List}

Apter, D. E. \& Saich, T. 1994, Revolutionary Discourse in Mao's Republic. Harvard University Press, Cambridge, MA.

Bailey, S. 2011, 'New Slogan, Old tricks: Zhang Dali in New York,' Yishu (Journal of Contemporary Chinese Art), vol. 10, no. 5: 99-106.

Barmé, G. 2009, 'China’s Flat Earth, 8 August 2008,' The China Quarterly, no. 197: 64-86. 2011, 'China's Prosperous Age (Shengshi)', China Heritage Quarterly, no. 26, Special Issue. Online, available: http://www.chinaheritagequarterly.org/editorial.php?issue $=026$ (Accessed 2 April 2012).

Benjamin, W. 1999, The Arcades Project. Harvard University Press, Cambridge, MA.

Brady, A. 2007. Marketing Dictatorship: Propaganda and Thought Work in Contemporary China. Rowman \& Littlefield, Lanham, MD. 2009, 'The Beijing Olympics as a Campaign of Mass Distraction,' The China Quarterly, no. 197: $1-24$.

Braester, Y. 2010, Painting the City Red: Chinese Cinema and the Urban Contract. Duke University Press, Durham, NC.

Broudehoux, A. 2008, 'Seeds of Dissent: The Politics of Resistance to Beijing's Olympic Rredevelopment,' in Dissent and Cultural Resistance in Asian Cities, (eds) M. Butcher \& S. Velayutham. Routledge, London: 28-46.

CCTV. 2006. 'Daguo jueqi' xilie congshu' (Accompanying book series to Daguo jueqi). Zhongguo minzhu fazhi, Beijing.

CCTV. 2007. Daguo jueqi (Rise of the Great Nations). 3 vols. Zhongguo minzhu fazhi, Beijing.

Chan Koonchung, D. M. (trans.) 2011, The Fat Years. Doubleday, London. [Original Title: 盛世: 中国, 2013 (Shengshi: Zhongguo, 2013)].

Cho, K. 2007 'Organizers Strive for a "Civilized" Sheen,' 8 August. Online, available: http://edition.cnn.com/2007/WORLD/asiapcf/08/03/olympics.manners/index.html\#cnnSTCPhoto (Accessed 20 October 2011).

De Certeau, M. 1980. L'Invention du Quotidien. Vol. 1, Arts de Faire. Union générale d'éditions, Paris: $10-18$.

1984, The Practice of Everyday Life, (trans.) S. Rendall. University of California Press, Berkeley.

Debord, G. 1995, The Society of Spectacle. Zone Books, New York.

Foucault, M. 1973, Ceci n'est pas une pipe. Fata Morgana, Montpellier. 1980, Power/Knowledge: Selected Interviews and Other Writings 1972-1977, (ed.) C. Gordon. Pantheon, New York. 1991, 'Governmentality,' in The Foucault Effect: Studies in Governmentality, (eds) G. Burchell, C. Gordon \& P. Miller. Harvester Wheatsheaf, Hemel Hempstead: 87-104. 2002, The Archaeology of Knowledge, (trans.) S. Smith. Routledge, London \& New York. 2004, Naissance de la biopolitique. Cours au Collège de France, 1978-1979. Gallimard/Seuil, Paris. 2007, Security, Territory, Population. Lectures at the Collège de France, 1977-78. Palgrave, New York.

Goldkorn, J. 2010, 'Chan Koonchong Interviewed by Jeremy Goldkorn for danwei.org,' 24 June. Online, available: http://www.youtube.com/watch?v=UCVYaEAeZq4 (Accessed 12 December 2011).

Harvey, D. 2008, 'The Right to the City,' New Left Review, no. 53: 23-40.

Ji, F. 2004, Linguistic Engineering: Language and Politics in Mao's China. University of Hawai'i Press, Honolulu.

Landsberger, S. R. 2004, 'Propaganda Posters in the Reform Era: Promoting Patriotism or Providing Public Information?,' in Asian Economic and Political Issues, vol. 10 (Asian Economic and Political Issues), (ed.) F. Columbus. Nova Science Publishers, New York: 27-57. 2005, 'Socialist Spiritual Civilization,' in Encyclopedia of Contemporary Chinese Culture, (ed.) E. L. Davis. Routledge, London: 556-57.

Landsberger, S. R., Kloet, B. J., \& Chong, G. P. L. 2010, 'National Image Management Begins at Home: Imagining the New Olympic Citizen,' in Soft Power in China: Public Diplomacy through Communication, (ed.) J. Wang. Palgrave Macmillan, New York: 117-33.

Lefebvre, H. 1991, The Production of Space. Blackwell, Oxford. 1996, Writing on Cities. Wiley-Blackwell, New York.

Li Zhengliang. 2006, 'Liangli de Qiangguomeng' (The Splendid Dream of the Strong Nation) Dushu, no. 1: $60-65$. 
Lu Xun. 1918, 'Kuangren riji’ (A Madman’s Diary), in Lu Xun Quanji, I, 422-433; Selected Works, I: 821. 1921, 'Guxiang' (My Old Home). In Lu Xun Quanji, I, 476-486; Selected Works, I, 63-75. 1956, Selected Works by Lu Xun, (trans.) Yang Hsien-yi \& G. Yang. Foreign Languages Press, Beijing. 1981, Lu Xun Quanji (Complete Works of Lu Xun), Renmin Wenxue, Beijing.

Marinelli, M. 2004, 'Walls of Dialogue in the Chinese Space,' China Information, vol. 18, no. 3, 429-461. Marinelli, M. 2009, 'Names and Reality in Mao Zedong's Political Discourse on Intellectuals,' Transtext(e)s Transcultures, no. 5. Online, available: http://transtexts.revues.org/index 268.html [Accessed 20 October 2011].

Perry, E. J. 2008, 'Chinese Conceptions of "Rights": From Mencius to Mao-and Now,'Perspectives on Politics, March, vol. 6, no. 1:37-50.

Porteous J. D. \& Smith S. E. 2001, Domicide: The Global Destruction of Home. McGill-Queen's University Press, Montreal \& Kingston.

Schoenhals, M. 1992, Doing Things with Words in Chinese Politics: Five Studies. University of California Berkeley, Berkeley.

Smith, T. 2008, 'Current of Contemporaneity: Architecture in the Aftermath,' Architectural Theory Review, vol. 11, no. 2, 2006, 34-52.

Sontag, S. 1977, On Photography. Penguin, London.

Terkenli, T. S. 2002, 'Landscapes of Tourism: Towards a Gglobal Cultural Economy of Space,' Tourism Geographies, vol. 4, no. 3: 227-54.

Wang Hongying. 2007, “Linking Up with the International Track": What's in a Slogan?,' The China Quarterly, no. 189: 1-23.

Wang Hui. 2003, China's New Order: Society, Politics, and Economy in Transition. Harvard University Press, Cambridge, MA. 2009, The End of the Revolution: China and the Limits of Modernity. Verso, London.

Wang Yang. 2011, 'Nuli jiakuai zhuanxing shengji, Jianshe Xingfu Guangdong (Accelerating Transformation and Upgrading: Building Happy Guangdong).' Speech given by the Guangdong Party Secretary on 6 January. Online, available: http://wenku.baidu.com/view/519e88886529647d27285292.html (Accessed 12 October 2011).

Yang Dongping (ed.) 2005, Xin gongmin duben (A New Citizenship Reader). Beijing daxue chubanshe, Beijing.

Yang Lian. 1998, 'Zai Zhongwenzhinei' (Inside the Chinese Language), Jintian, no. 1, 208-12.

Zhang Dali. 2006, A Second History, (ed.) Wu Hung. Walsh Gallery, Chicago. 2008a, 'Guanyu "kouhao" xilie de zishu' (Artistic statement on the Slogan Series). Unpublished document written in April 2008. 2008b, 'Slogans.' Kiang Gallery press release September 12-October 18. Online, available: http://www.artnet.com/Galleries/Exhibitions.asp?gid=602\&cid $=144988 \&$ source $=2 \&$ type $=2$ (Accessed 9 September 2011). 